\title{
臼歯部崩壊に対する咬合再構成
}

清水幹広

\section{An Occlusal Reconstruction Approach to Restoring Posterior Bite Collapse}

\author{
Mikihiro Shimizu
}

When the therapeutic occlusion aiming at functional recovery is given, the most important thing is shifting to therapeutic occlusion, following investigating the cause of occlusal collapse and solving the problem.Clear examination and diagnosis is performed, the treatment goal was determined, the exact treatment plan for the goal is formed, and advancing each step certainly becomes the key to the successful treatment.In this article, the case diagnosed as occlusion trauma caused bite collapse will be presented.Also, the dental treatment procedures for this case will be discussed.The process led to the treatment goal to the case was divided into four items of aesthetic, function, structure dynamics, and biostability. And it is the case which shifted to the final prosthetic treatment, evaluating, respectively, and performed occlusal reconstruction.

機能と審美の回復を目的とした治療咬合を与える際にもっとも重要なことは, なぜ咬合 崩壊に至ったかという原因を追究し，その問題を解決してから治療咬合へ移行することで ある。明確な診査診断を基に治療ゴールを導き，ゴールに対する的確な治療計画を立て， 一つひとつのステップを確実に進めていくことが治療を成功させる鍵となる。 今回, 咬合 性外傷が起因となり崩壊を招いたと診断し, 治療ゴールへ導く過程を審美, 機能, 構造力 学，生体安定性の 4 項目に分け，それぞれ評価しながら最終補綴に移行し，咬合再構成を 行った症例を提示して, 治療の進め方を考察してみたい.

Key words : 診查診断 Examination and Diagnosis, 顔貌・ 口唇との調和 Harmony of Face and Lips, 顎位 Mandibular Position, 修復物の選択 Choices of Materials, 生体安定性 Biostablity 

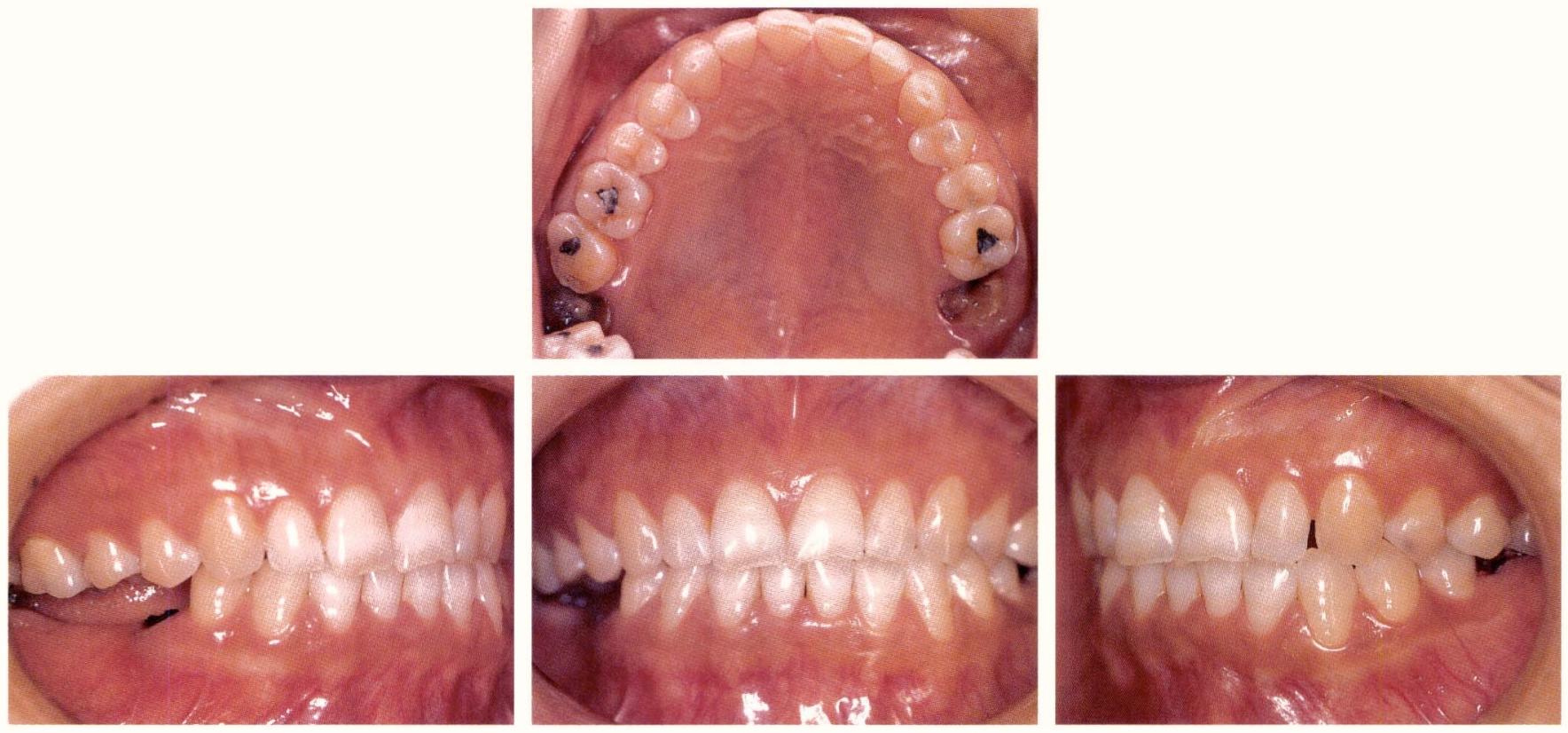

図 1 a 初診時正面観，b 右側側方面観，C 左側側方面観，d 上顎咬合面観，e 下顎咬 合面観.

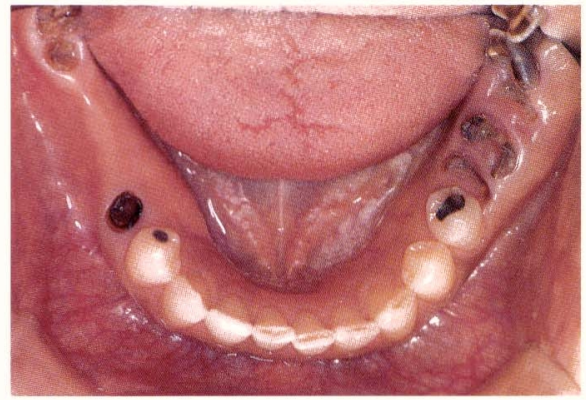

\section{症例}

患者； 43 歳 女性

初診：平成 11 年 11 月 9 日

主訴：奥歯で物が噛めない。

現病歴：数年前より左右の下顎自歯部補緅物脱離，残根状 態である。

TMJ : 右側にクリック音を週 1, 2 回程度認める。疼痛, 開口障害は認めない。

既往歴：特記すべき事項はなし。

\section{1. 初診時 顔貌・口腔内所見}

顔貌においては, 顔面の中心線 (垂直線) と歯牙の正中 が一致していない。また8 $81785 \mid 678$ 残根, 上下前歯部扔 よび7の咬耗が著明である. 3 の歯頸線が反対側に比べ て下がっている，上下歯列弓のバランスは比較的良好であ る。上顎右側，下顎左側自菌部の挺出を認めた。

2. 初診時 $X$ 線写真 デンタル, パノラマ

残根以外寸べて有髄歯，65|45にカリエスを認める。歯
根膜腔の拡大や特異的な骨の吸収はなく, 全体的に骨レベ ルは安定している。 678 は骨からの挺出を伴う。ペリオ, カリエスリスクは低いと思わ机る(図2)。

\section{3. 診査診断}

初診時, どこまで治療すべきなのか, 欠損部だけの治療 でよいのか, 残存歯も含めて治療する必要があるのか, ま たどのように考え進めていけばよいのか非常に悩むケース であった。そこでまず問題点を抽出し，それぞれの原因と 原因除去に何が必要かを考えていった。

\section{4. 問題点}

・なぜ残根になっているのか？

・なぜ咬耗は起こったのか？

・上下の正中のずれは？

. 骨格の評価?

·顎位 $\mathrm{CO}-\mathrm{CR}$ の評価?

·治療の範囲は?

以上の問題点を一つ一つ診査診断していく. 


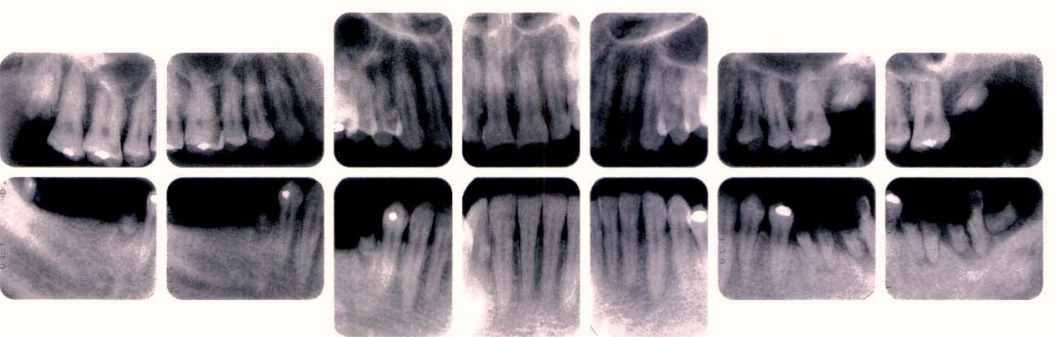

図2 初診時 $X$ 線写真. デンタル, パノラマ.
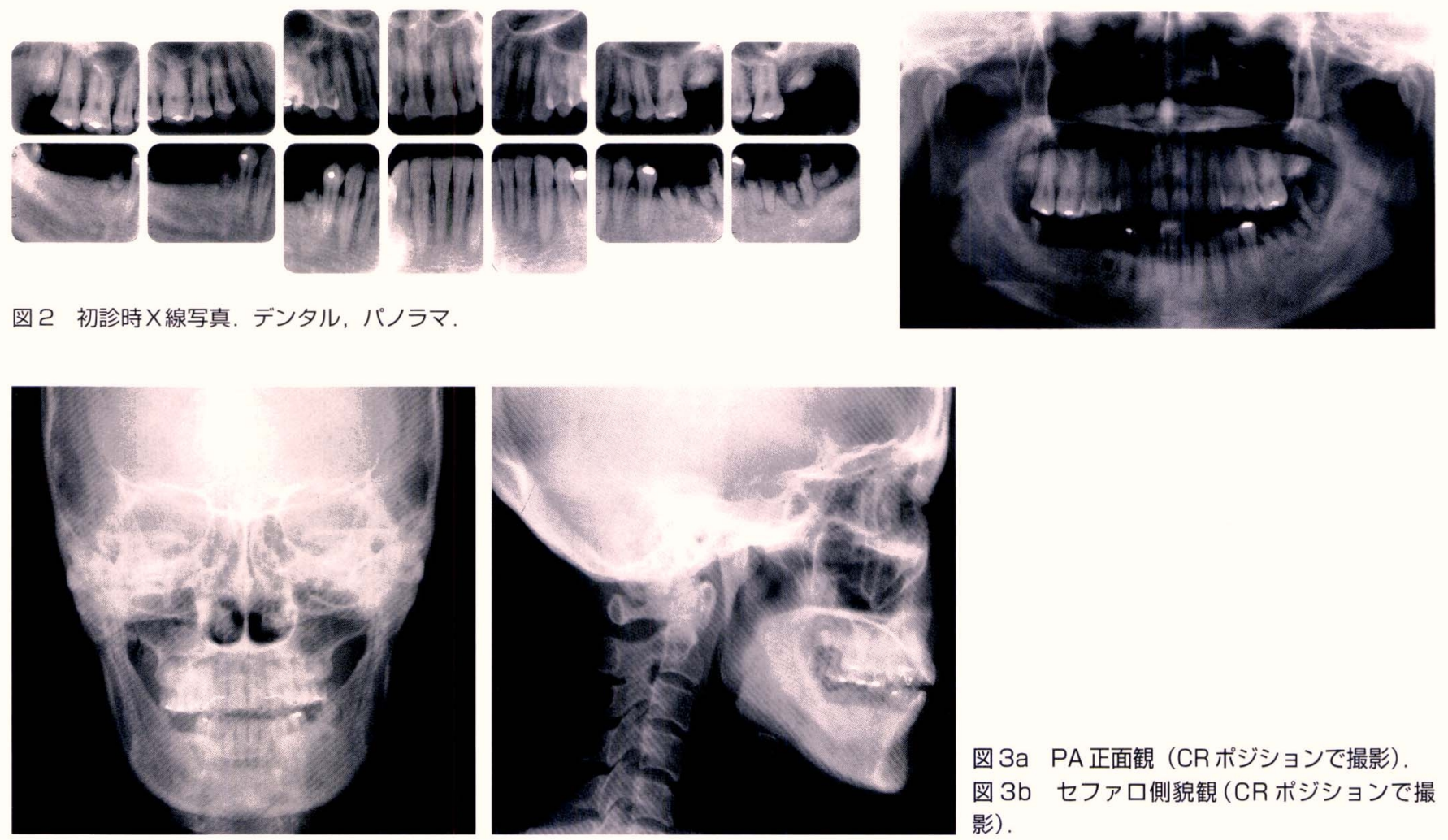

図 3a PA 正面観 (CRポジションで撮影).

図 3b セファロ側貌観 (CR ポジションで撮 影).

1）なぜ残根になっているのか？

残根が多いわりに残存歯の状態はそれほど悪くないこと や問診より，きっかけは小さなカリエスと思われるが，下 顎臼歯部には補綴処置がされていたと推測される．上顎の 対合関係，特に7の咬合面を見ると，咬合性外傷が起き ていたと考えられる。 それが二次カリエスや脱離を招いて, 長期間放置していたため残根状態になったと診断した。

\section{2）なぜ咬耗は起こったのか？}

残存している前歯部と臼歯部にかなりの咬耗を認める. これは，７の咬合面を見てもわかるように，咬合性外傷が 原因である。また, 補綴物が脱離し， 臼歯部で咬めないこ とから前咬み状態になり,さらに顎位が左側前方に偏位し たため, より咬耗が強くなってきた。 3 の歯頸線が反対側 に比べて下がっているのも，左側前方に力がかかってきた ためと診断した。

\section{3）上下の正中のずれは?}

PAより骨格的な左右の対称性, 下顎枝の長さ, 方向, 正面からの咬合平面の評価を行う（図 3a). セファロ側貌 観より側方からの上下顎の位置関係，骨格に対する歯牙の 位置関係, 歯軸, 位置関係を評価する (図 3b).

中心位でのPAより左右骨格は対称的，上下顎の正中は
骨格の正中に一致する，セファロより側方からの骨格も正 常と判断する。つまり骨格, 歯牙のポジションは問題なく, 下顎位のずれ，つまり顎位の偏位と診断した。次にどの程 度のずれ (偏位) なのかが重要となる。

\section{4) 顎位 CO-CR の評価 ?}

安定した下顎位 CR ポジションをスプリントにより模索 する。スプリントを装着することにより(図 4a, b)，ク リック音が消失してきたことや，「装着時の方が顎は安定 している」という患者のコメント，また，上下の正中が 揃ったことなどから，下顎位は安定した位置にきていると 診断した(正中が一致することが必ずしも CR ポジション とはいえないが，一つの目安にはなる）。

$\mathrm{CR}$ と CO を比較すると, $\mathrm{CO}$ では上顎の正中に対して, 下顎の正中が左側に偏位している。臼歯部での咀嚼が不可 能なため, 前咬みの状態である (図 5a). CR ポジション では，上下の正中が一致し右側第一小臼歯が当たる．上下 前歯部間 (特に左側)に空隙を認める (図 5b).

\section{5）治療範囲は?}

欠損部のみの補綴修復 (インプラント補綴)をした場合， 実際に機能しはじめると, 本来この患者の咬みたい位置, 安定した位置，つまり CR (右側後方)で咬むのではないか 

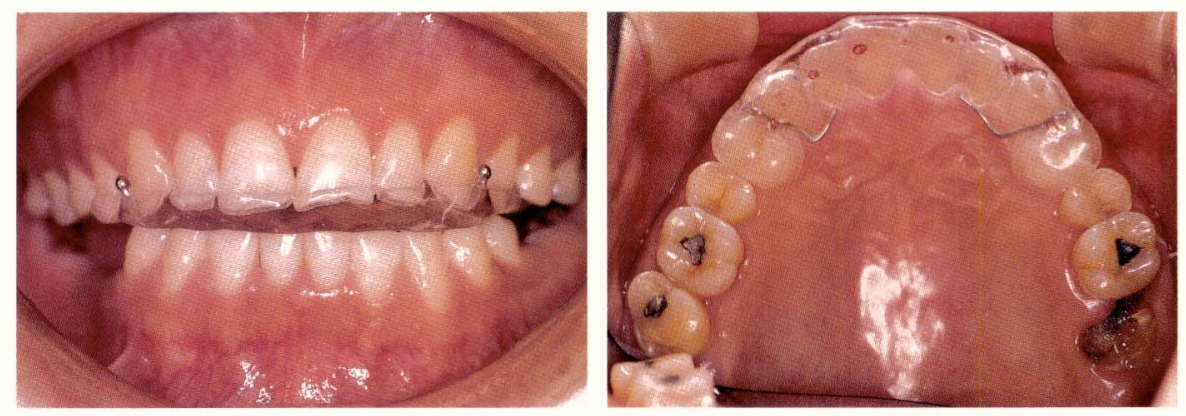

図 5a CO (咬頭嵌合位).

図 5b CR (中心位).
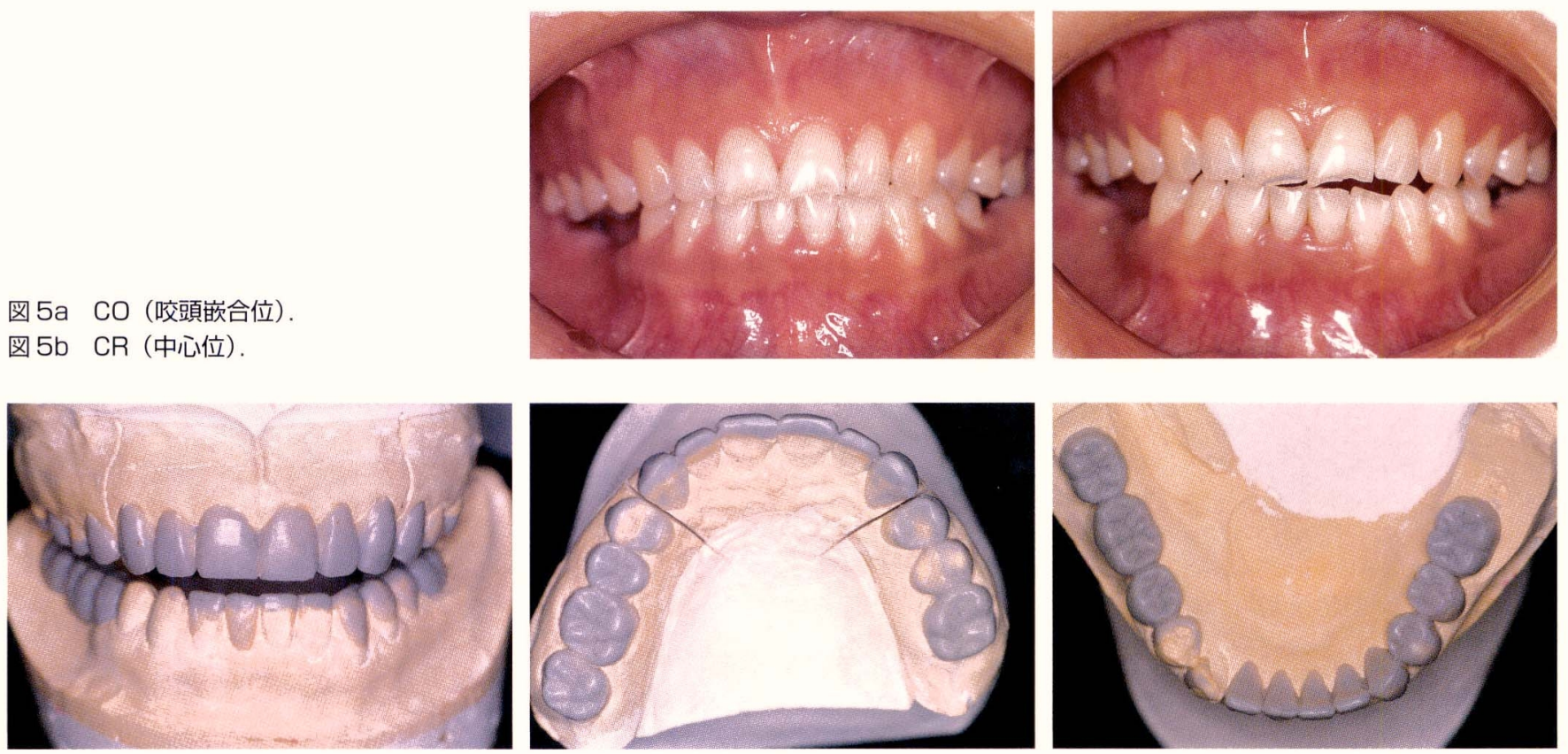

図6a〜c＼cjkstart診断用ワックスアップ.

と考えられる。そうなると，インプラント，もしくは上部 構造，また対合歯の崩壊を招くおそれがある。やはり CR での修復がこのケースでのポイントになるといえる. 図 5b見てもわかるように犬歯の関係は，右側は比較的よ いが，左側ではかなり距離があり，アンテリアガイダンス もとれない. 上䫁臼歯の挺出を考えると, 下䫁臼歯部だけ の補経処置というレベルではなく, フルマウスでの治療が 必要だと診断した。

\section{5. 治療目標と治療ゴール}

審美：骨格, 顔貌との調和 咬合平面，歯頸ライン，スマ イルラインのバランスを整える.

機能：スプリントで求めた安定した下顎位で，バーティカ ルストップ，アンテリアガイダンスを与える。

構造力学：欠損部にはインプラントを, 残存歯においては

$$
\text { オールセラミックスを用いる。 }
$$

生体安定性：歯周組織との調和をはかる。

\section{6. 治療ゴールの設定}

スプリントより求めた CR での診断用ワックスアップを 作製、前歯部のカップリングを行い，アンテリアガイダン スを確立し, バーティカルストップの確保, また最終補綴 をイメージしながら, 咬合平面, 審美的な歯の位置, 軸方 向，形態，バランスを考慮し機能的な咬合を与えることが 重要である。咬合高径の決定に関しては，CRの位置を基 準に，右側犬歯が接触するところまで右側第一小臼歯を調 整し，固有の咬合高径よりわずかに上がっている位置に決 定. また咬耗して低くなっている分を上げて, 本来あった 状態に近つけた(図6).

\section{7. モックアップ}

診断用ワックスアップからレジンにてエステティックジ グを作製し, 歯牙に張り付け, 全体的なバランス, 軟組織 との調和を見る。歯老削る前に, 術者, 患者ともに術後の 評価ができ，安心して治療に入ることができる(図7). 

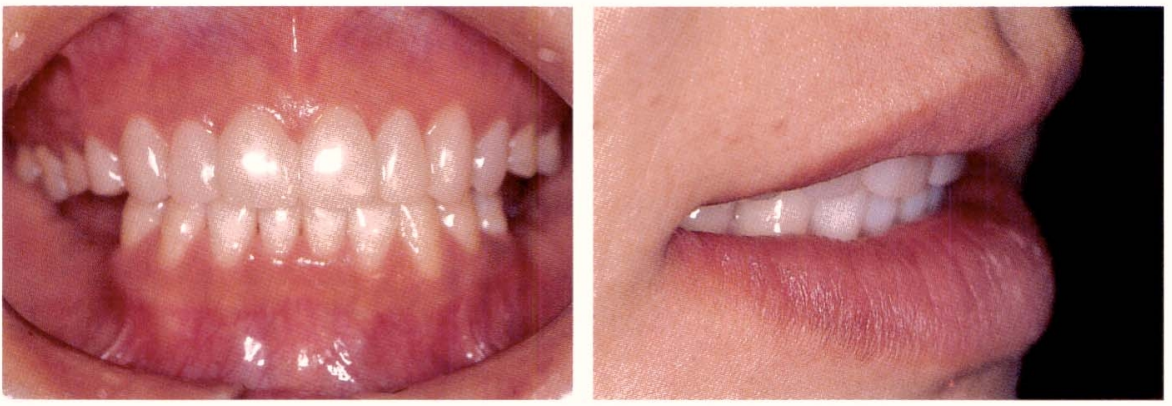

図 7a，b モックアップ. 正面観と側方から 見たリップとの関係
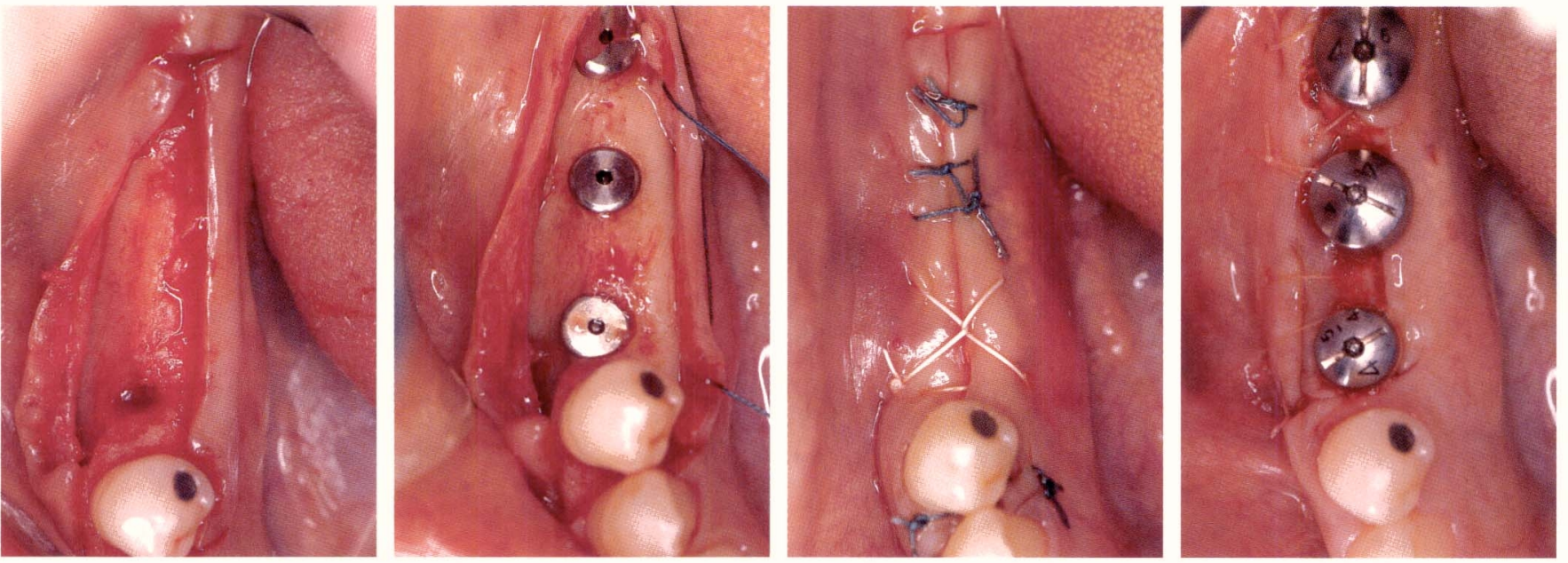

図 8a〜c インプラント埋入， d 二次手術

ここまでが診査診断である，問題占を一つひとつ検証す ることによって治療ゴールが明確になり，迷うことなく本 格的な治療に入ることができる.

\section{8. 治療}

1) インプラント埋入

診断用ワックスアップからサージカルステントを作製 し，近遠心，煩舌的な位置を確定し，インプラント埋入を 行う（図 $8 a 〜 c)$ ．術前にレントゲンによる下歯槽管まで の距離の計測, 骨幅, 歯肉の厚さ, 付着歯肉の評価などが 必要である。 6 の抜歯時には骨の挺出を伴っていたため, 補緅時の歯頸レベルを考慮して骨整形も同時に行ってい る。また，煩側の骨幅の少ない 5 は $\mathrm{GBR}$ を行う。二次手 術時にはヒーリングアバットメントを装着し，角化歯肉が 少ないため付着歯肉を側方移動させた(図 8d)。

\section{2）顎位の再確認}

インプラント部にプロビジョナルを立ち上げ，臼歯部の 咬合が可能になった時点で顎位の再確認をした(図9a,b).

\section{3）診断用ワックスアップ2}

最終補緅，削除量，マテリアルを決定するために，より 細かい診断用ワックスアップ2を行う(図9).

水平的に被蓋関係，咬合平面，切端ライン，最大豊隆う イン, 歯頸ライン，コンタクトライン，垂直的に正中，歯 軸，歯冠幅径，犬歯の関係，アーチのバランス，連続性な どを評価する(図10).

\section{4）最終補緅へ移行}

診断用ワックスアップより作製したプロビジョナルおよ びモックアップから，術後の審美的，機能的評価を行い, 最終補経へ移行する(図11)。

\section{9. 最終補綴設計}

審美的，生体安定性を考えて，インプラント上部構造以 外全顎オールセラミックスを選択し，形成のデザインや削 除量は診断用ワックスアップより決定した(図 12).

1) シークエンシャルセメンテーション（形成・印象・最 終補緅装着)

- 順序 下顎前歯最終補綴装着 (図 13a) $\Rightarrow$ 上顎前歯最終 


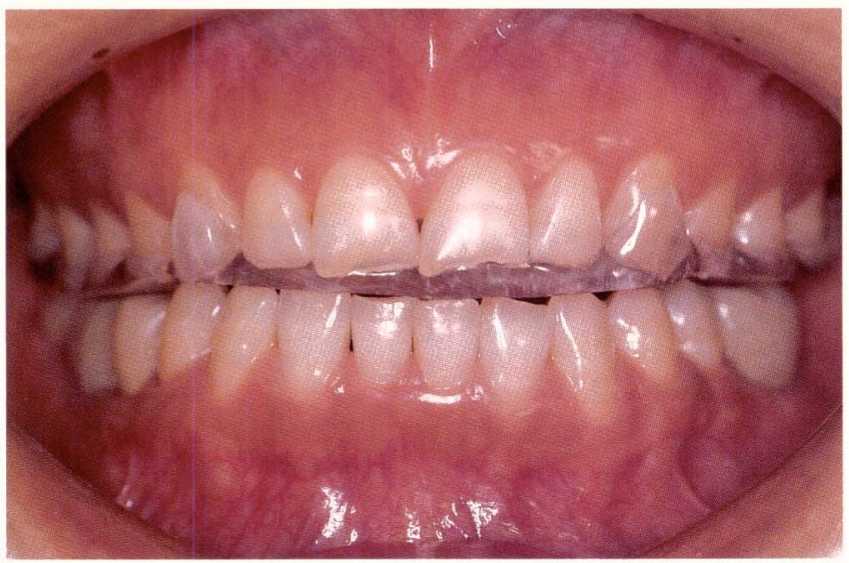

図 9a, b スプリントによる顎位の再確認.

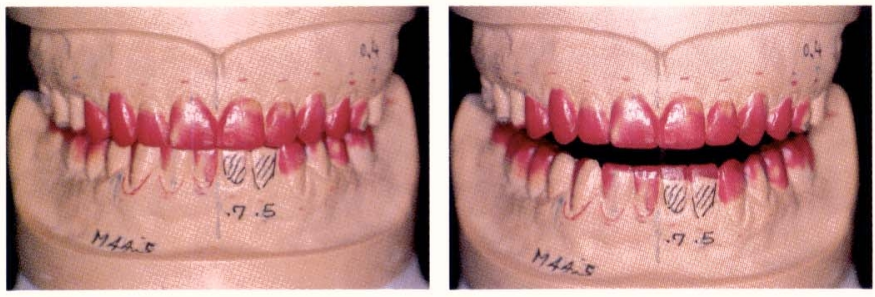

図 10a〜d＼cjkstart診断用ワックスアップ2

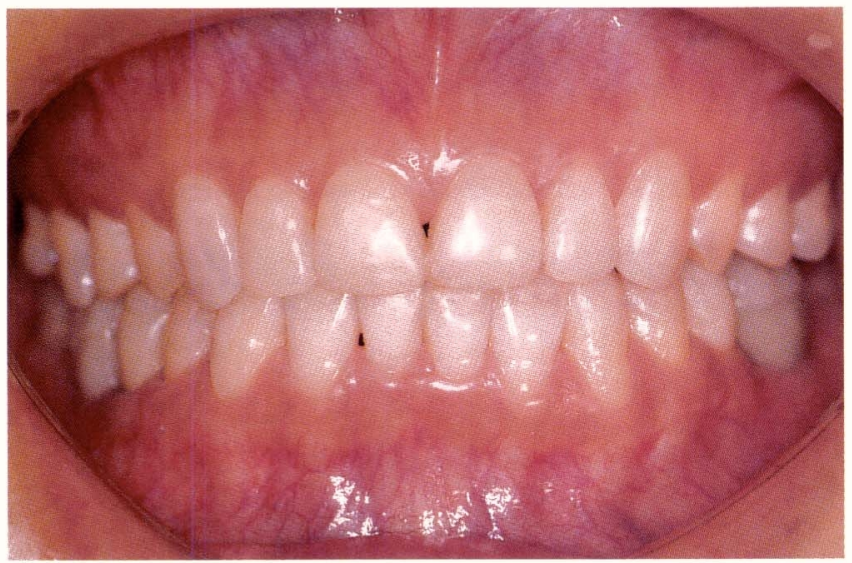

図 11 モックアップとプロビジョナルの状態.
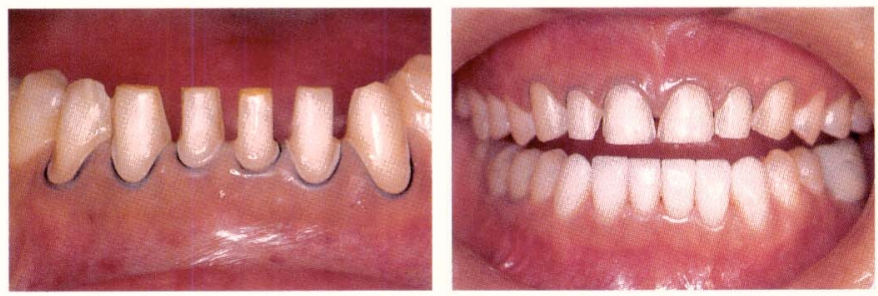

図 13a〜d ブロックごとの最終形成.

補綴装着 (図 13b) $\Rightarrow$ 下顎臼歯 (図 13c) $\Rightarrow$ 上頡臼歯 (図 13d）の順でブロックごとに形成, 印象, 最終補緅物を セットしていく.

下顎 6 前歯で切端を揃え (咬合平面の基準)，それに対し
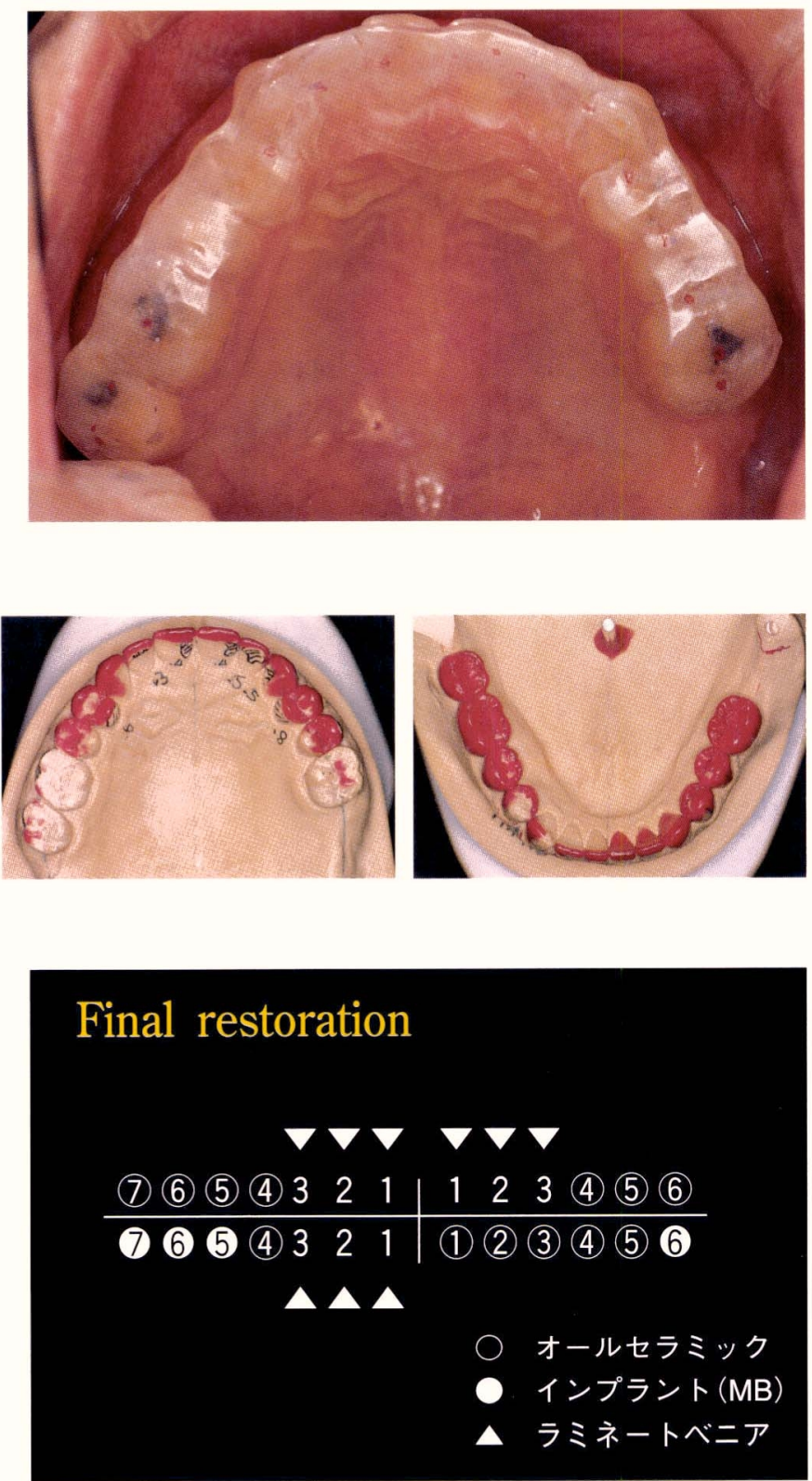

図 12 最終補緅設計
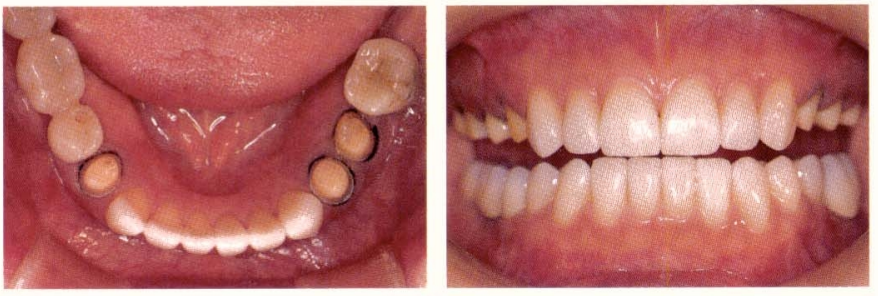

上顎前歯を当てる(この時点で, 顆頭の位置はスプリント により求めた安定した位置であり，その位置でアンテリア ガイダンスが確立されたことになる)，次に下顎臼歯を下 顎前㐘にあわせて (咬合平面を揃えて) 作っていく。下顎 顎咬合誌 第24巻 第2 · 3 合併号 2004 | 341 

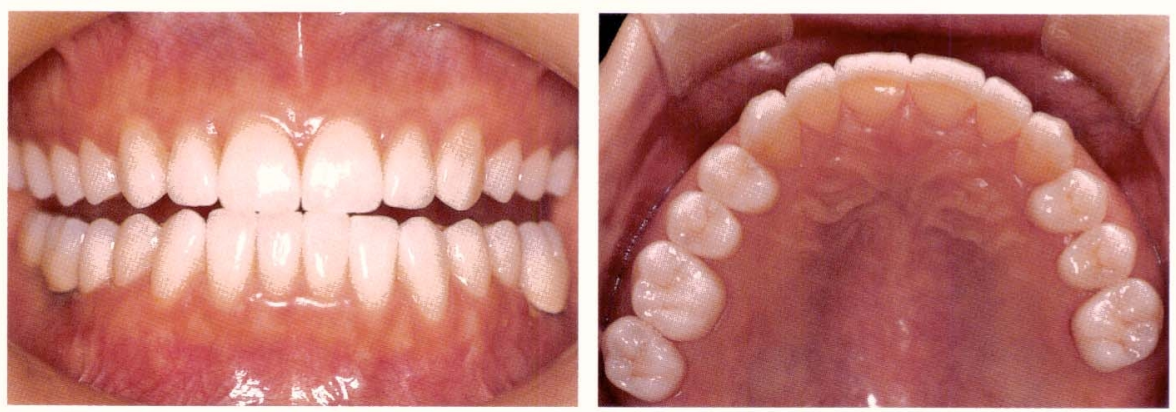

$\frac{a b \mid}{c d e}$

f g g h

図 14 術後の口腔内写真（最終補経）。

a 前方ガイド，b 上顎咬合面観，c 右側側 方面観，d 正面観，e 左側側方面観， $f$ 右 側方ガイド，g 下顎咬合面観， h 左側方ガ イド.
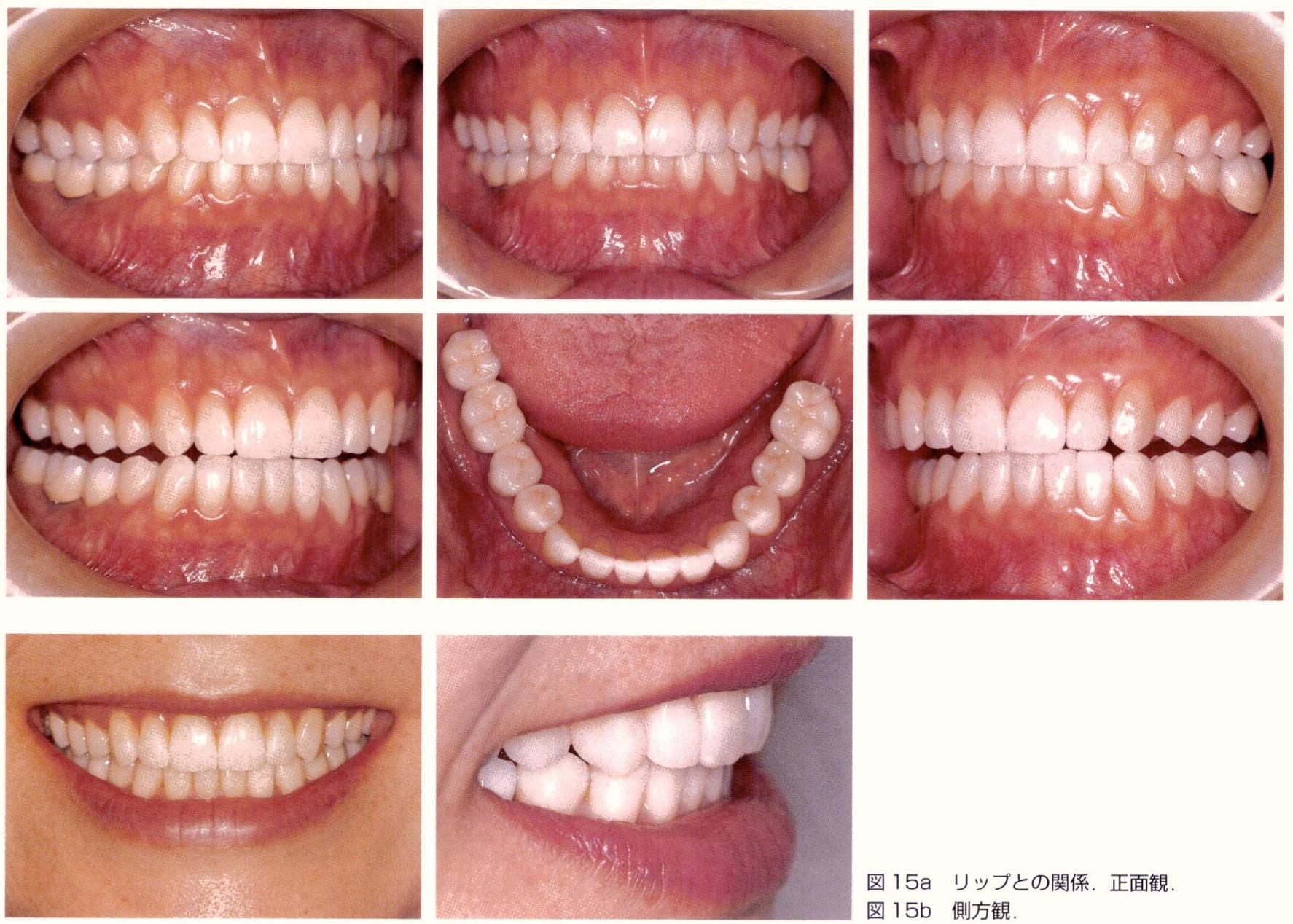

図 15a リップとの関係．正面観. 図 15b 側方観.

の平面がそろった段階で最後に上顎の臼歯部へ移る。

\section{0. 最終補緅}

診断用ワックスアップ2のように, 上下の正中は一致し 咬合平面が揃い適切な被蓋関係を得ることができた。 犬歯 関係も良好で側方運動時の臼歯離開 (ディスクルージョン) を認め, 上下の咬合面観を見ると，歯列弓のバランス，歯 牙の連続性（煩側咬頭・中心溝・舌側咬頭）は保たれてい 万(図 14).

また，軟組織との調和，口唇とのバランスも全体的には
良好である (図 15a, b). 術後のデンタルX線写真に拈 いては, インプラント以外の部位では, 天然歯様の像にみ え, 個々の歯周組織は安定している(図 16).

11. オールセラミックス, ラミネートベニア

メタルを使用しないため，色調の再現性にすぐれ，より 自然感が得られ，また歯肉に対しての阻害性も少なく，審 美性，生体恒常性が保たれている。顎は 6 前歯べニア， 下顎は右側ベニア，左側はフルクラウンであるが，ブラッ クトライアングルや，歯頸部からの形態を変える必要があ 

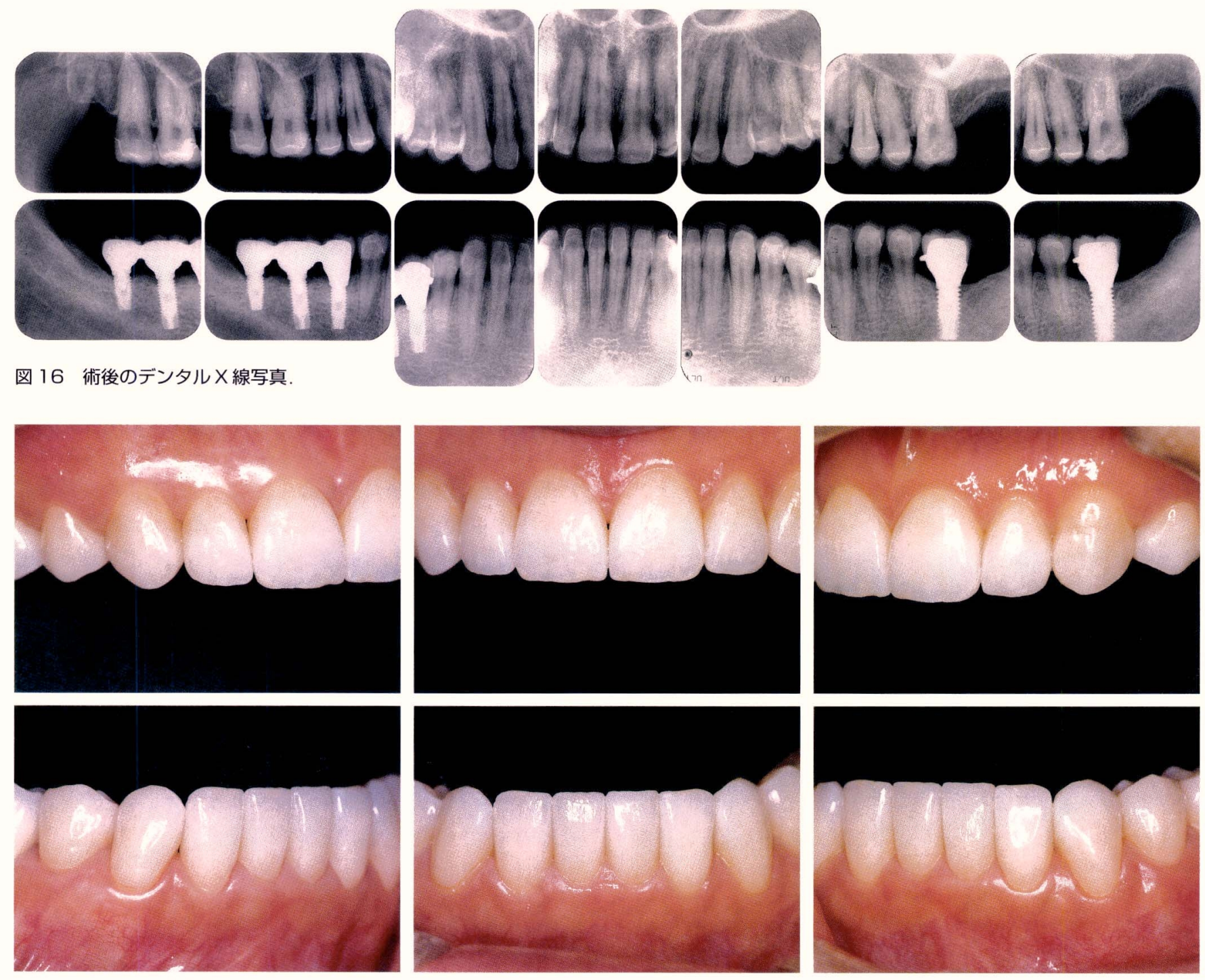

図 17a〜 f 上下前歯部のオールセラミックス・ラミネートベニア修復.

る場合など，フィニッシュラインの深さや頬舌的な位置を 考慮する必要がある。また，審美的要素は言うまでもない が，歯質の保全や強度，歯肉に対する侵襲など考えると， これからの審美修復において第一選択になると考える(図 $17 a \sim f)$.

以上，診断(初診) から最終補経までの流れと考え方を 述べた，次に反省点を挙げる。

\section{1. 反省点}

1) 審美

(1)45の歯頸ラインが歯冠側に下がっている.61のクラウ ンレングスニングの際，同時に行うべきであった(図 15a).

(2)下頂前歯部の形態がスクエアー的に見える。これはエン
ブレジャーを気にするあまり，コンタクトを詰めすぎた ためと考える。エッジを絞り形態修整をする必要があっ た。

2) 機能

スプリントにより求めた安定した下顎位での，アンテリ アガイダンス，インプラントによるバーティカルストップ が確立され, 前方, 側方運動時のディスクルージョンを得 ることができ，機能的には比較的安定したと考えられる.

3）構造力学（ストラクチャー）

インプラント以外すべて有髄歯ということで，支台歯に 対しては安心感はあるが，ベニアやオールセラミックスク ラウンに拈いて, 確実にボンディングできているかがポ 


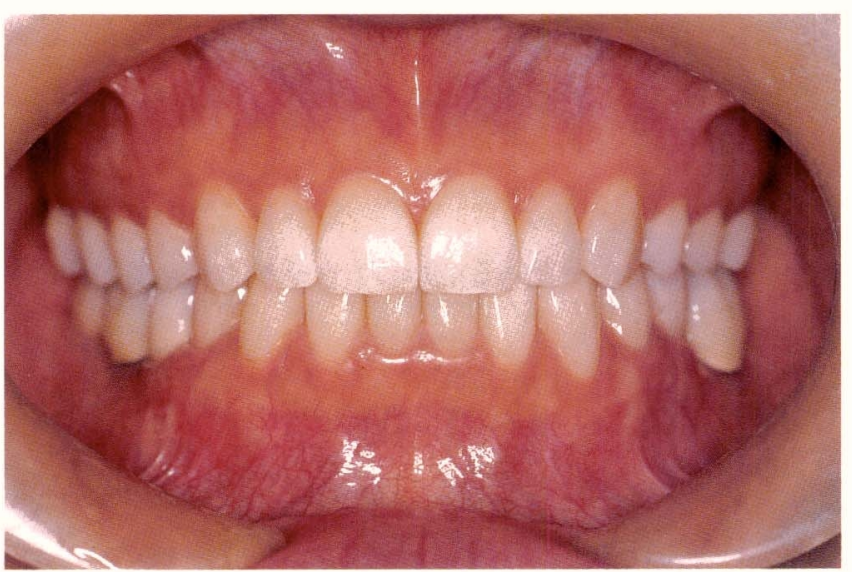

図18 正面観、可の歯頸ラインが下がっている.

イントとなる。また， 6 にエクスターナルのアバットメン 卜を単独に用いたことでスクリューの緩みが生じてこない か不安が残る。

\section{4）生体安定性}

歯肉に対してはメタルを使用していないため, 為害性も 少なく, フィニッシュラインも通常のメタルボンドより浅 めに設定することできた。また顎関節及び周囲の筋肉に対 しても，クリック音の消失や左右対称性などから初診時よ り安定したと思われる。

また，各々の項目に関係してくるが，残根抜歯時に最終

\section{参考文献}

1）山崎長郎, 本多正明：臨床歯周補綴 $I$, 第一出版, 東京, 1992.

2）山崎長郎：審美修復治療, クインテッセンス出版, 東京, 1999.

3）山崎長郎監修, 今井俊広, 今井真弓, 小出馨 佐藤利英 : 著, 臨床咬合補綴治療の理論と実践, 別冊クインテッセ ンス, クインテッセンス出版, 東京, 2003.
補経のことを考えて骨形成まで行ったが， 6 のインプラン トポジションが頬側よりになってしまい結果的には歯頸線 を下げてしまった。

\section{まとめ}

本ケースのように, 初診時にどこまで治療すべきなのか, どうすべきかと悩むことがよくあるが（つまりゴールが見 えないケース, 複雑なケース), そのような場合, 問題点 を一つひとつ抽出していき，それぞれに対する原因を追究 し，原因除去には何が必要かということを検証していくと ゴールが見えてくる。つまり，【診断】がもっとも重要と なってくる，先ほど挙げた反省点にしても術前にわかるこ とがほとんどである。どのようなケースに拀いても的確に 䛦断したうえで治療ゴールを設定し，そして治療計画を立 案してから治療に取り組むことがもっとも大切であること を痛感した，今後も診査診断の重要性を忘れずに日々の臨 床に携わっていきたいと考えている。

\section{謝辞}

このような投稿の機会を与えてくださった林 揚春先生, 日頃の臨床でアドバイスをいただく木原敏裕先生, 細川 孔先生，補綴に関してご指導をいただいた歯科技工士の(有) ファイン桜井保幸氏, 当クリニックのスタッフ, 患者さん に心から感謝いたします。

4) Pascal Magne, Urs Belser 著, 山崎長郎監修：ボンディッド ポーセレンレストレイションズ。クインテッセンス出版, 東京, 2002 .

5）ラミネートベニアテクニック，歯科技工別冊，医歯薬出版， 東京, 2003.

6）細川 孔：審美と機能の回復, QDT 別冊 Esthetic of Dental Technology, クインテッセンス出版, 東京, 1999. 